Review

\title{
Effects of Extracorporeal Shock Wave Therapy on Spasticity in Patients after Brain Injury: A Meta-analysis
}

\author{
Jin-Youn Lee, $\mathrm{MD}^{1)}$, Soo-Nyung Kim, MD, $\mathrm{PhD}^{2)}$, In-Sik Lee, MD, PhD ${ }^{1)}$, \\ Heeyoune Jung, MD ${ }^{1)}$, Kyeong-Soo Lee, PT, MSc ${ }^{1)}$, Seong-Eun Koh, MD, $\mathrm{PhD}^{1)^{*}}$ \\ 1) Department of Rehabilitation Medicine, Konkuk University Medical Center and Konkuk University \\ School of Medicine, Konkuk University: 120-1 Neungdong-Ro, Gwangjin-Gu, Seoul 143-729, \\ Republic of Korea \\ 2) Department of Obstetrics and Gynecology, Konkuk University Medical Center and Konkuk \\ University School of Medicine, Konkuk University, Republic of Korea
}

\begin{abstract}
Purpose] The purpose of this meta-analysis was to assess the effects of extracorporeal shock wave therapy (ESWT) on reducing spasticity immediately and 4 weeks after application of ESWT. [Subjects and Methods] We searched PubMed, TCL, Embase, and Scopus from their inception dates through June 2013. The key words "muscle hypertonia OR spasticity" were used for spasticity, and the key words "shock wave OR ESWT" were used for ESWT. Five studies were ultimately included in the meta-analysis. [Results] The Modified Ashworth Scale (MAS) grade was significantly improved immediately after ESWT compared with the baseline values (standardized mean difference [SMD], $-0.792 ; 95 \%$ confidence interval [CI], -1.001 to -0.583 ). The MAS grade at four weeks after ESWT was also significantly improved compared with the baseline values (SMD, $-0.735 ; 95 \%$ CI, -0.951 to -0.519 ). [Conclusion] ESWT has a significant effect on improving spasticity. Further standardization of treatment protocols including treatment intervals and intensities needs to be established and long-term follow up studies are needed.

Key words: Spasticity, Extracorporeal shock wave therapy, Meta-analysis
\end{abstract}

(This article was submitted Feb. 27, 2014, and was accepted Apr. 10, 2014)

\section{INTRODUCTION}

After injury to the upper motor neurons (UMN) such as the brain or spinal cord, certain clinical deficits present immediately or at delayed times. Weakness and loss of dexterity appear at an early stage followed by various degrees of muscle overactivities. Spasticity or spastic hypertonia elicited by passive stretch of a muscle at rest can interfere with active or passive movement ${ }^{1}$. Hyperexcitability of spinal reflexes causes spasticity and spastic hypertonia, but it is not the only mechanism that contributes to spasticity after brain injury. Recent studies indicate that abnormal stretch reflex activity is insufficient to explain increased muscle tone ${ }^{2-4)}$. Increased stiffness of a muscle during stretching due to changes in collagen tissue and tendons, enhancement of the intrinsic stiffness of muscle fibers, and loss of sarcomeres can lead to subclinical contractures ${ }^{5}$.

Each of the therapeutic interventions to reduce spasticity including physical therapy, occupational therapy, orthoses,

* Corresponding author. Seong-Eun Koh (E-mail: kohse@ kuh.ac.kr)

(C2014 The Society of Physical Therapy Science. Published by IPEC Inc. This is an open-access article distributed under the terms of the Creative Commons Attribution Non-Commercial No Derivatives (by-ncnd) License $<$ http://creativecommons.org/licenses/by-nc-nd/3.0/>. pharmacological treatment, chemodenervation, orthopedic surgery, and neurosurgery has different indications and advantages ${ }^{6}$. There is currently a lack of specific guidelines for the stratification and individualization of therapeutic interventions.

Extracorporeal shock wave therapy (ESWT) was first applied to patients in 1980 to break up kidney stones ${ }^{7)}$, and later it was successfully employed for many orthopedic diseases such as nonunion of long bone fracture ${ }^{8)}$, plantar fasciitis $^{9,10)}$, calcifying tendinitis of the shoulder ${ }^{11,12)}$, and several inflammatory tendon diseases ${ }^{13)}$; myofascial pain syndrome $\left.{ }^{14}, 15\right)$; and treatment of spasticity. The mechanisms of how ESWT induces the healing process in human tissue remain uncertain, but recent studies suggest that ESWT appears to involve a cascade of interaction between physical shock wave energy and biologic responses including the expression of angiogenesis-related growth factors such as eNOS (endothelial nitric oxide synthase), VEGF (vessel endothelial growth factor), and PCNA (proliferating cell nuclear antigen) and neovascularization ${ }^{16-19)}$. The indications for ESWT in orthopedic disorders continue to expand $^{13)}$.

Recently, clinical trials have been performed to evaluate the efficacy of ESWT. However, each study adopted different clinical scales that were insufficient to draw a definite conclusion about the efficacy of ESWT in reducing spas- 
ticity after brain injury. To suggest a firm conclusion, we searched for studies published up to June 2013 and metaanalyzed the efficacy of ESWT in reducing spasticity after brain injury.

\section{SUBJECTS AND METHODS}

We searched PubMed, TCL, Embase, and Scopus from their inception dates through June 2013 to identify interventional studies using ESWT to improve spasticity in patients with brain lesion. First, we searched PubMed and TCL records using the following criteria: ((Muscle OR Muscular) AND (Spastic* OR Hypertonia* OR Hypertonicit*)) OR (Muscle Tone Increased OR Spasticity) AND (Shock Wave* OR ESWT). Second, we searched Embase using the following criteria: (muscle hypertonia'/exp OR (muscle OR muscular AND (spastic* OR hypertonia* OR rigidit*)) OR (muscle AND tone AND increased) OR spastic*) AND (shock wave'/exp OR shock wave* OR 'ESWT'). Third, we searched Scopus using the following criteria: ((muscle OR muscular) AND (spastic* OR hypertonia* OR rigidit*)) AND (shock wave* OR "ESWT"). Seventy-three studies were retrieved. Two reviewers working independently screened all the abstracts and the titles for the candidate studies and discarded the studies in which extracorporeal shock waves were used for different purposes other than spasticity. After the initial screening, they reviewed the full text publications for eligibility, and disagreements between the two reviewers were resolved by consensus. Only studies written in English were selected.

All of the studies using ESWT for the purpose of ameliorating spasticity in patients with any brain injury were included. The studies involving other concomitant interventional procedures, such as botulinum toxin injection, were excluded. We included the studies that provided both baseline and postprocedure Modified Ashworth Scale (MAS) grades for selected muscles. The MAS grade was assessed immediately after application of ESWT in all included studies. Among them, four studies suggested MAS grade which was assessed 4 weeks after application of ESWT. The MAS grade ranged from 0 to 4 , with 0 indicating no increase in muscle tone and 4 indicating rigid in flexion and extension.

From the selected studies, we abstracted data regarding follow-up durations, pre- and postprocedure MAS grades, and MAS grades at four weeks after ESWT, and compared them between time intervals.

MAS grades were statistically analyzed. Mean \pm standard deviation values for pre- and postprocedure MAS grades and for the MAS grades at four weeks after ESWT were provided in all studies. Heterogeneity refers to the differences between studies in terms of methodological factors, such as use of blinding and concealment of allocation. Significant statistical heterogeneity arising from methodological diversity or differences in outcome assessments suggests that the studies are not all estimating the same quantity but does not necessarily suggest that the true intervention effect varies. A number of options are available if statistical heterogeneity is identified among a group of studies that would otherwise be considered suitable for a meta- analysis $^{20)}$. Heterogeneity was calculated by the Cochrane $\mathrm{Q}$ statistic test and the $I^{2}$ test $\mathrm{t}^{21)}$. The $I^{2}$ test describes the rate of variation across studies due to heterogeneity rather than chance and ranges from 0 (no heterogeneity) to 100 (maximum heterogeneity). All results are reported with $95 \%$ confidence intervals $(95 \% \mathrm{CI})$, and all $\mathrm{p}$-values are two-tailed. When a significant heterogeneity among the outcomes was found $\left(I^{2}>50\right)$, the random effects model according to DerSimonian-Laird was used ${ }^{22}$. This model assumes that the true treatment effects in individual studies may be different from one another and that these treatment effects are normally distributed. Those outcomes that did not present with heterogeneity $\left(I^{2}<50\right)$ were analyzed with the fixed-effects model. The fixed-effects model uses the inverse variance approach, and it is assumed that all studies come from a common population. Subgroup analysis was also used to detect heterogeneity according to the muscle groups assessed in each study. The MAS grades assessed immediately after ESWT $\left(I^{2}=0.0 \%\right)$ and 4 weeks after ESWT $\left(I^{2}=\right.$ $0.0 \%$ ) were analyzed by the fixed-effects model. Because of the small number of studies in each subgroup, we used a funnel plot, Begg's test, and Egger's test simultaneously to detect publication bias. Begg's and Egger's tests are recommended when there is insufficient evidence ${ }^{23)}$. The analysis was performed using Comprehensive Meta-Analysis version 2.0 (Biostat, Englewood, NJ, USA).

\section{RESULTS}

The primary search for the effect of ESWT on spasticity in patients with brain injury identified 73 relevant studies, and 32 duplicate studies were discarded. Thirty-four studies were excluded after screening of their abstracts. Two studies were additionally excluded: one study used botulinum toxin injection before application of ESWT, and the other study presented insufficient data for meta-analysis. Ultimately, five studies were included in the meta-analysis. Four studies examined the spasticity of the ankle plantar flexor, and one study examined wrist and finger flexors (Table 1, Fig. 1). For quality assessment of the studies included in this meta-analysis, the Newcastle-Ottawa Scale was used (Table 2 ). The characteristics of the intervention and relevant outcome measurements for each study are described in Table 3.

Five studies assessed the effects of ESWT on improvement of the MAS grade immediately after application of ESWT. Six groups from 5 studies were evaluated. The MAS grade was significantly improved after ESWT compared with the baseline values (standardized mean difference [SMD], $-0.792 ; 95 \% \mathrm{CI},-1.001$ to $-0.583 ; \mathrm{p}<0.001$ ) (Fig. 2). Significant inter-study heterogeneity was not found $\left(\chi^{2}=2.53, \mathrm{p}=0.77, I^{2}=0.0 \%\right)$. Begg's test $(\mathrm{p}=0.09)$ and Egger's test $(\mathrm{p}=0.06)$ suggested that some bias source might be included in this sample of studies, but the classic fail-safe $\mathrm{N}$ was 83 . Therefore, we concluded that the selected studies were not biased. Funnel plot analysis was also performed (Fig. 3A). We also performed a subgroup analysis based on the tested muscles, and it did not show any different results (Fig. 4A).

The MAS grade was also assessed four weeks after ap- 
Table 1. Studies that evaluated the effect of extracorporeal shock wave therapy

\begin{tabular}{|c|c|c|c|c|c|c|c|c|c|c|c|c|c|}
\hline \multirow{3}{*}{$\begin{array}{c}\text { Year } \\
\text { Published }\end{array}$} & \multirow{3}{*}{ Author } & \multirow{3}{*}{ Population } & \multirow{3}{*}{$\begin{array}{l}\text { Tested } \\
\text { muscle }\end{array}$} & \multirow{3}{*}{$\begin{array}{c}\text { No. } \\
\text { of } \\
\text { patients }\end{array}$} & \multirow{3}{*}{$\begin{array}{l}\text { Follow- } \\
\text { up } \\
\text { (weeks) }\end{array}$} & \multicolumn{8}{|c|}{ Modified Ashworth Scale } \\
\hline & & & & & & \multicolumn{2}{|c|}{ Baseline } & \multicolumn{2}{|c|}{ After ESWT } & \multirow{2}{*}{$\begin{array}{c}\mathrm{p}- \\
\text { value }\end{array}$} & \multicolumn{2}{|c|}{$\begin{array}{c}4 \text { weeks } \\
\text { after ESWT }\end{array}$} & \multirow{2}{*}{$\begin{array}{c}\mathrm{p}- \\
\text { value }\end{array}$} \\
\hline & & & & & & Mean & SD & Mean & SD & & Mean & $\mathrm{SD}$ & \\
\hline 2013 & $\begin{array}{c}\text { Gonokova } \\
\text { et al. }\end{array}$ & $\begin{array}{c}\text { Cerebral } \\
\text { palsy }\end{array}$ & $\begin{array}{l}\text { Plantar } \\
\text { flexor }\end{array}$ & 25 & 4 & 2.70 & 0.09 & 2.00 & 0.08 & 0.001 & 2.15 & 0.07 & 0.001 \\
\hline 2010 & $\begin{array}{l}\text { Amelio } \\
\text { et al. }\end{array}$ & $\begin{array}{c}\text { Cerebral } \\
\text { palsy }\end{array}$ & $\begin{array}{l}\text { Plantar } \\
\text { flexor }\end{array}$ & 12 & 12 & 3.30 & 0.49 & 1.80 & 0.38 & 0.001 & 2.25 & 0.45 & 0.001 \\
\hline \multirow{2}{*}{2005} & \multirow{2}{*}{$\begin{array}{l}\text { Manganotti } \\
\text { et al. }\end{array}$} & \multirow{2}{*}{ Stroke } & $\begin{array}{l}\text { Wrist } \\
\text { flexor }\end{array}$ & 20 & 12 & 3.40 & 0.70 & 2.00 & 0.90 & 0.001 & 2.30 & 0.70 & 0.001 \\
\hline & & & $\begin{array}{l}\text { Finger } \\
\text { flexor }\end{array}$ & 20 & 12 & 3.20 & 0.60 & 0.80 & 0.40 & 0.001 & 1.30 & 0.40 & 0.001 \\
\hline 2013 & $\begin{array}{l}\text { Moon } \\
\text { et al. }\end{array}$ & Stroke & $\begin{array}{l}\text { Plantar } \\
\text { flexor }\end{array}$ & 30 & 4 & 2.50 & 0.67 & 1.41 & 0.67 & 0.002 & 1.75 & 0.62 & 0.019 \\
\hline 2011 & $\begin{array}{l}\text { Sohn } \\
\text { et al. }\end{array}$ & Stroke & $\begin{array}{l}\text { Plantar } \\
\text { flexor }\end{array}$ & 10 & - & 2.67 & 1.15 & 1.22 & 1.03 & 0.035 & & - & \\
\hline
\end{tabular}

ESWT $=$ extracorporeal shock wave therapy

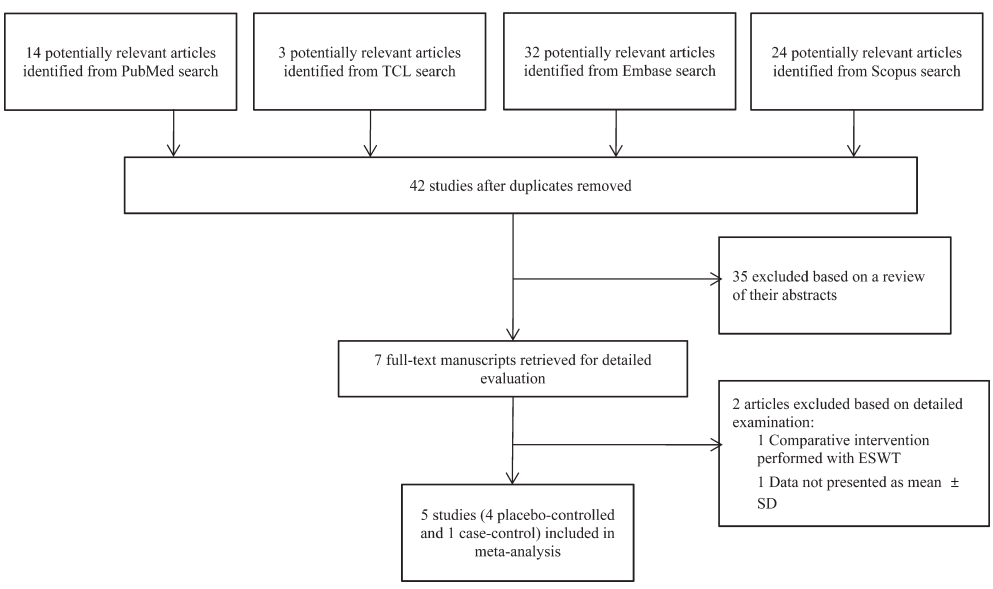

Fig. 1. Flow diagram of the study selection process

Table 2. Quality assessments using the Newcastle-Ottawa Scale

\begin{tabular}{|c|c|c|c|c|}
\hline \multirow{2}{*}{$\begin{array}{c}\text { Year } \\
\text { published }\end{array}$} & \multirow{2}{*}{ Author } & \multicolumn{3}{|c|}{ Newcastle-Ottawa Scale } \\
\hline & & Selection & Comparability & Exposure \\
\hline 2013 & Gonokova et al. & $* * * *$ & * & $* *$ \\
\hline 2010 & Amelio et al. & $* * * *$ & $*$ & $* *$ \\
\hline 2005 & Manganotti et al. & $* * * *$ & $*$ & $* *$ \\
\hline 2013 & Moon et al. & $* * *$ & * & $* *$ \\
\hline 2011 & Sohn et al. & $*$ & - & $* * *$ \\
\hline
\end{tabular}

plication of ESWT. Five groups in 4 studies were evaluated. The MAS grade was significantly improved after ESWT compared with the baseline values (standardized mean difference [SMD], $-0.735 ; 95 \% \mathrm{CI},-0.951$ to $-0.519 ; \mathrm{p}<0.001)$ (Fig. 5). Significant inter-study heterogeneity was not found $\left(\chi^{2}=4.706, p=0.319, I^{2}=14.994 \%\right)$. Begg's test $(\mathrm{p}=0.05)$ and Egger's test $(\mathrm{p}=0.009)$ suggested that some bias source might be included in this sample of studies. However, the classic fail-safe $\mathrm{N}$ was 59 . Therefore, we concluded that the selected studies were not biased. Funnel plot analysis was also performed (Fig. 3B). We also performed a subgroup analysis based on tested muscles, and it did not show any different results (Fig. 4B).

\section{DISCUSSION}

Spasticity, as defined by Lance in 1980, is a motor disorder characterized by a velocity-dependent increase in tonic stretch reflexes ("muscle tone") with exaggerated tendon jerks, resulting from hyperexcitability of the stretch reflex, as one component of upper motor neuron syndrome ${ }^{24)}$. The pathophysiology of spasticity and hypertonus is complex and not clearly understood yet. Different spinal and supraspinal pathways contribute to it, and multiple neuronal mechanisms lead to increased reflex excitability. Even though spasticity and hypertonus provide some benefits to patients $^{25}$ ), most of the result of the spasticity may be detrimental. Spasticity can cause discomfort and stiffness and 
1644 J. Phys. Ther. Sci. Vol. 26, No. 10, 2014

Table 3. Characteristics of intervention, outcome, and results of the individual studies in our review

\begin{tabular}{|c|c|c|c|}
\hline Study & Energy / pressure & Dosage and treated muscles & Relevant outcome \\
\hline $\begin{array}{l}\text { Gonokova et al. } \\
\text { (2013) }\end{array}$ & 1.5 bar & $\begin{array}{l}1,500 \text { shots each in the gastrocnemius and } \\
\text { soleus }\end{array}$ & $\begin{array}{l}\text { PROM } \\
\text { MAS } \\
\text { Baropodometric measurement }\end{array}$ \\
\hline $\begin{array}{l}\text { Amelio et al. } \\
(2010)\end{array}$ & $0.030 \mathrm{~mJ} / \mathrm{mm}^{2}$ & $\begin{array}{l}1,500 \text { shots each in the gastrocnemius and } \\
\text { soleus }\end{array}$ & $\begin{array}{l}\text { PROM } \\
\text { MAS } \\
\text { Baropodometric measurement }\end{array}$ \\
\hline $\begin{array}{l}\text { Manganotti et al. } \\
(2005)\end{array}$ & $0.030 \mathrm{~mJ} / \mathrm{mm}^{2}$ & $\begin{array}{l}1,500 \text { shots for the flexor muscles of the } \\
\text { forearm and } \\
3,200 \text { shots for the interosseus muscles of } \\
\text { the hand ( } 800 \text { shots for each muscle) }\end{array}$ & $\begin{array}{l}\text { PROM } \\
\text { MAS } \\
\text { CMAP latency and amplitude } \\
\text { F-wave latency and amplitude }\end{array}$ \\
\hline $\begin{array}{l}\text { Moon et al. } \\
(2013)\end{array}$ & $0.089 \mathrm{~mJ} / \mathrm{mm}^{2}$ & 1,500 shots in the gastrocnemius & $\begin{array}{l}\text { PROM } \\
\text { MAS }\end{array}$ \\
\hline $\begin{array}{l}\text { Sohn et al. } \\
\text { (2011) }\end{array}$ & $0.2 \mathrm{~mJ} / \mathrm{mm}^{2}$ & 1,500 shots in the gastrocnemius & $\begin{array}{l}\text { MAS } \\
\text { CMAP latency, amplitude, conduction velocity } \\
\text { F-wave latency } \\
\text { H-reflex latency } \\
\text { H-M ratio }\end{array}$ \\
\hline
\end{tabular}

PROM = passive range of motion; MAS = Modified Ashworth Scale; CMAP = compound muscle action potential

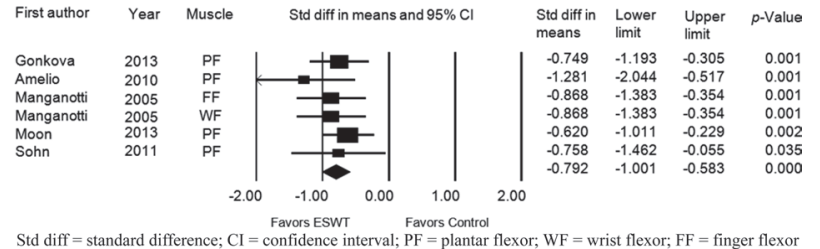

Fig. 2. Forest plot of the effect assessed immediately after extracorporeal shock wave therapy

Std diff = standard difference; $\mathrm{CI}=$ confidence interval; $\mathrm{PF}=$ plantar flexor; $\mathrm{WF}=$ wrist flexor; $\mathrm{FF}=$ finger flexor

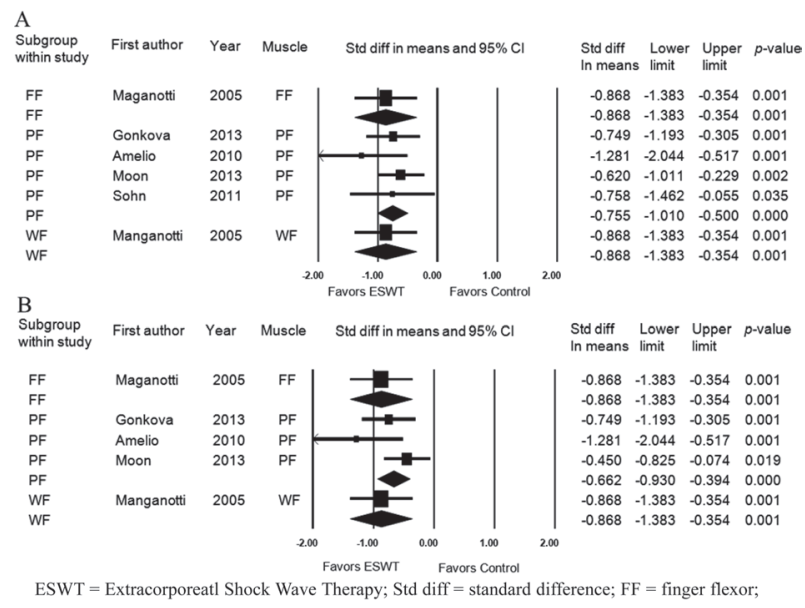

$\mathrm{PF}=$ plantar flexor; $\mathrm{WF}=$ wrist flexor

Fig. 4. Forest plot of the subgroup analysis to assess for heterogeneity depending on muscle groups assessed immediately (A) and 4 weeks (B) after extracorporeal shock wave therapy ESWT $=$ Extracorporeatl Shock Wave Therapy; Std diff $=$ standard difference; $\mathrm{FF}=$ finger flexor; $\mathrm{PF}=$ plantar flexor; $\mathrm{WF}=$ wrist flexor
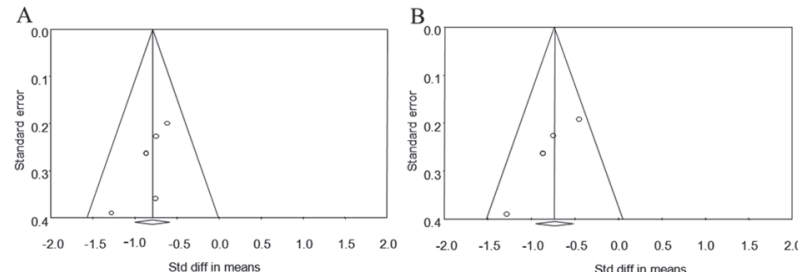

MAS = Modified Ashworth Scale; ESWT $=$ Extracorporeal Shock Wave Therapy; $\begin{aligned} & \text { Std diff in means } \\ & \text { Stff }=\text { standard difference }\end{aligned}$

Fig. 3. Funnel plots to assess for publication bias at the time immediately (A) and 4 weeks (B) after extracorporeal shock wave therapy

MAS = Modified Ashworth Scale; ESWT = Extracorporeal Shock Wave Therapy; Std diff = standard difference

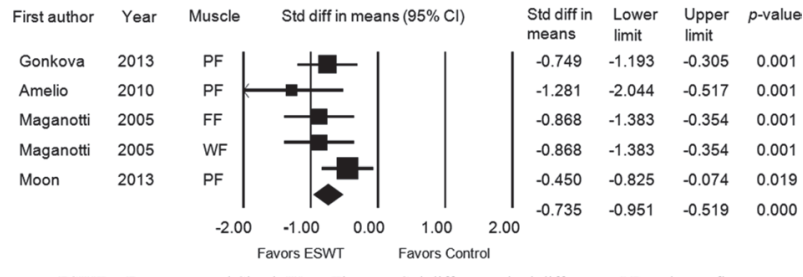

ESWT = Extracorporeal Shock Wave Therapy; Std diff = standard difference; PF = plantar flexor; $\mathrm{FF}=$ finger flexor; $\mathrm{WF}=$ wrist flexor

Fig. 5. Forest plot of the effect assessed 4 weeks after extracorporeal shock wave therapy ESWT $=$ Extracorporeal Shock Wave Therapy; Std diff $=$ standard difference; $\mathrm{PF}=$ plantar flexor; $\mathrm{FF}=$ finger flexor; $\mathrm{WF}=$ wrist flexor

limitations in physical activities such as walking, transferring, picking up objects, washing, dressing, or sexual activity $^{26)}$. Four of the studies included in this meta-analysis evaluated the reduction of spasticity in ankle plantar flexors because it has a major functional implication in gait in patients with cerebral palsy or stroke ${ }^{27-30)}$. Poorly managed 
spasticity of the plantar flexors is responsible for muscle shortening and the development of tendon and soft tissue contractures, leading to an impaired swing phase of gait. One of the studies evaluated spasticity of wrist and finger flexors in patients affected by stroke because it may seriously impair hand functions and activities of daily living ${ }^{31)}$.

A number of pharmacological agents and non-pharmacological treatments such as physical therapy, orthoses, and transcutaneous electrical nerve stimulation (TENS) have been tried for the treatment of spasticity and hypertonus ${ }^{32}$. Chemodenervation also called neurolysis or neuromuscular blockade are used to prevent nerve-muscle transmission with perineural injection of phenol ${ }^{33,34)}$ or ethyl alcohol ${ }^{35)}$ and intramuscular injection of botulinum toxin ${ }^{36-41)}$. More invasive treatment options such as rhizotomy ${ }^{42-44)}$ and intrathecal baclofen ${ }^{45-48)}$ could be another choice for patients who are resistant to conventional treatments or have intractable spasticity. Treatment of spasticity needs to be performed with a stepped care approach that begins with simple and reversible treatments that have few side effects and proceeds to irreversible treatments that have more side effects.

Botulinum toxin injection has been tried in many studies and proven to be effective on improving muscle spasticity ${ }^{36-41)}$. However, the efficacy of botulinum toxin injection has been challenged by several reasons. The formation of neutralizing antibodies after botulinum toxin injection happens in more than one-third of dystonic patients who are labeled as "nonresponders"49). Other reasons for the lack of response to botulinum toxin injections are inappropriate dosing, changes in the pattern of muscle involved, incorrect injection sites, reconstitution, and/or storage failure ${ }^{50)}$.

The indications for ESWT, which was first applied for lithotripsy ${ }^{7)}$, have expanded to a variety of orthopedic diseases over the last decades. Two different mechanisms of the effect of ESWT are noted; one mechanism of effect is the high positive pressure and short rise time, which are responsible for the direct shock wave effect, and the other is the tensile wave for the cavitations, which is called the indirect shock wave effect ${ }^{51)}$. However, the mechanism of how the ESWT affects spasticity remains uncertain. Nitric oxide has a very important physiological function in the central nervous system and in the transmission of the nerve impulse in the neuromuscular junction ${ }^{52)}$. A number of studies have investigated the effect of ESWT by inducing enzymatic and nonenzymatic nitric oxide synthesis ${ }^{17,53)}$. Although, it has been suggested that nitric oxide plays an important role in regulating inflammatory events, biomechanical mechanisms underlying these effects have yet to be elucidated ${ }^{19)}$.

Although the etiology of spasticity is central, secondary changes in peripheral nerves and muscles are critical factors in producing spasticity. Therefore, most of therapeutic interventions are focused on these secondary changes. There are structural and functional changes in spastic skeletal muscle. Most published micrographs of muscle from spastic patients showed abnormalities such as increased fiber size variability, increased number of rounded fibers, moth-eaten fibers, and increased extracellular space. In addition, spastic muscles present increased joint stiffness, and this is presumably due to fibrosis within the muscle tissue or an increase in the number of crossbridges attached during contraction. Moreover, muscle contractures occur secondary to spasticity due to a reduction in muscle fiber length and a decrease in the number of serial sarcomeres within muscle fibers ${ }^{54)}$. One possible effect of ESWT is the improvement in connective tissue stiffness acting on fibrosis of chronic hypertonic muscles. These considerations are consistent with recent studies assessing the advantages of ESWT for several orthopedic and traumatic indications including problematic soft tissue wound ${ }^{55-57)}$.

When analyzing the results of ESWT for treatment of spasticity and hypertonus, adopting a reliable method for assessing spasticity is challenging. The Ashworth scale, first developed in 1964 ${ }^{58}$, is the best known scale for measuring the degree of spasticity ${ }^{26)}$. Among the clinical evaluation tools, the MAS which has a good interrater reliability, was adopted for comparing pre- and posttreatment changes in severity of spasticity in this meta-analysis. The metaanalysis indicated that ESWT improved the MAS grade significantly compared with the baseline values. In all studies, the MAS grade decreased in a statistically significant manner at the time immediately after ESWT and at four weeks after ESWT, and the SMDs and 95\% CIs were -0.792 and -1.001 to $-0.583(\mathrm{p}<0.001)$ and -0.735 and -0.951 to -0.519 $(\mathrm{p}<0.001)$, respectively.

There were some limitations to this study. The MAS, even though it is the most frequently cited rating scale for measurement of spasticity, does not evaluate the velocity of passive joint movement and the angle of contraction outbreak or potential tendon retraction ${ }^{59,60)}$. Also, even if this scale seems to measure the resistance adequately, the reduced range of joint motion due to contracture might limit its reliability ${ }^{61)}$.

Therefore, the MAS does not substantially reflect spasticity according to Lance's definition, that is, a motor disorder characterized by a velocity-dependent increase in muscle tone ${ }^{24)}$. On the other hand, the Modified Tardieu Scale does take into account the velocity of passive joint movement and assess the angle of catch and the speed at which the catch was obtained forms the basis of the measure of spasticity. In addition, the Modified Tardieu Scale is more sensitive in the detection of posttreatment changes because it measures muscle resistance as well as the velocity of the movement that induces muscular contraction ${ }^{62)}$.

Another limitation of the present study was that the MAS does not include clinical features including pain, spasm, and impact of function that could be associated with spasticity. The clinical impacts of spasticity that discourage patients include spasm or pain accompanied by hypertonicity; functional deterioration of activities of daily living such as walking, transferring, dressing and washing; and burden placed on caregivers. Therefore, other clinical assessment scales such as the visual analogue scale (VAS) for pain assessment, spasm frequency scale (SFS) or clonus score, daily functional assessment scales, and patient/caregiver goal assessment scale should be included in future studies.

A third limitation is the short follow-up periods in the 
included studies. The average follow-up duration was only 4 weeks in two studies and was 12 weeks in two other studies; the final study evaluated immediate effects of ESWT only. Therefore, it is difficult to suggest the optimal treatment interval from this meta-analysis. Long-term follow-up studies are needed in future studies.

\section{REFERENCES}

1) Sheean G, McGuire JR: Spastic hypertonia and movement disorders: pathophysiology, clinical presentation, and quantification. PM R, 2009, 1: 827-833. [Medline] [CrossRef]

2) Hufschmidt A, Mauritz KH: Chronic transformation of muscle in spasticity: a peripheral contribution to increased tone. J Neurol Neurosurg Psychiatry, 1985, 48: 676-685. [Medline] [CrossRef]

3) Galiana L, Fung J, Kearney R: Identification of intrinsic and reflex ankle stiffness components in stroke patients. Exp Brain Res, 2005, 165: 422434. [Medline] [CrossRef]

4) Sinkjaer T, Toft E, Larsen K, et al.: Non-reflex and reflex mediated ankle joint stiffness in multiple sclerosis patients with spasticity. Muscle Nerve, 1993, 16: 69-76. [Medline] [CrossRef]

5) Dietz V, Sinkjaer T: Spastic movement disorder: impaired reflex function and altered muscle mechanics. Lancet Neurol, 2007, 6: 725-733. [Medline] [CrossRef]

6) Frontera WR: Spasticity and muscle overactivity as components of the upper motor neuron syndrome. In: DeLisa's Physical Medicine \& Rehabilitation: principles and practice. Philadelphia: Lippincott Williams \& Wilkins, 2010, pp 1323-1337.

7) Chaussy C, Brendel W, Schmiedt E: Extracorporeally induced destruction of kidney stones by shock waves. Lancet, 1980, 2: 1265-1268. [Medline] [CrossRef]

8) Valchanou VD, Michailov P: High energy shock waves in the treatment of delayed and nonunion of fractures. Int Orthop, 1991, 15: 181-184. [Medline] [CrossRef]

9) Rompe JD, Decking J, Schoellner C, et al.: Shock wave application for chronic plantar fasciitis in running athletes. A prospective, randomized placebo-controlled trial. Am J Sports Med, 2003, 31: 268-275. [Medline]

10) Ronald VB, Dale M, James WF: An evaluation of research evidence fo selected physical therapy interventions for plantar fasciitis. J Phys Ther Sci, 2007, 19: 41-56. [CrossRef]

11) Rompe JD, Zoellner J, Nafe B: Shock wave therapy versus conventiona surgery in the treatment of calcifying tendinitis of the shoulder. Clin Orthop Relat Res, 2001, (387): 72-82. [Medline] [CrossRef]

12) Loew M, Daecke W, Kusnierczak D, et al.: Shock-wave therapy is effective for chronic calcifying tendinitis of the shoulder. J Bone Joint Surg Br, 1999, 81: 863-867. [Medline] [CrossRef]

13) Wang CJ: An overview of shock wave therapy in musculoskeletal disorders. Chang Gung Med J, 2003, 26: 220-232. [Medline]

14) Lee JH, Han EY: A comparison of the effects of PNF, ESWT, and TPI on pain and function of patients with myofascial pain syndrome. J Phys Ther Sci, 2013, 25: 341-344. [CrossRef]

15) Cho YS, Park SJ, Jang SH, et al.: Effects of the combined treatment of extracorporeal shock wave therapy (ESWT) and stabilization exercises on pain and functions of patients with myofascial pain syndrome. J Phys Ther Sci, 2012, 24: 1319-1323. [CrossRef]

16) Wang CJ, Huang HY, Pai CH: Shock wave-enhanced neovascularization at the tendon-bone junction: an experiment in dogs. J Foot Ankle Surg, 2002, 41: 16-22. [Medline] [CrossRef]

17) Ciampa AR, de Prati AC, Amelio E, et al.: Nitric oxide mediates anti-inflammatory action of extracorporeal shock waves. FEBS Lett, 2005, 579: 6839-6845. [Medline] [CrossRef]

18) Zhang $X$, Yan $X$, Wang $C$, et al.: The dose-effect relationship in extracorporeal shock wave therapy: the optimal parameter for extracorporeal shock wave therapy. J Surg Res, 2014, 186: 484-492. [Medline] [CrossRef]

19) Mariotto S, Cavalieri E, Amelio E, et al.: Extracorporeal shock waves: from lithotripsy to anti-inflammatory action by NO production. Nitric Oxide, 2005, 12: 89-96. [Medline] [CrossRef]

20) Cochrane Collaboration: Cochrane handbook for systematic reviews of interventions. Ver. 5.1.0. http://handbook.cochrane.org (Accessed Mar. 2011)

21) Hatala R, Keitz S, Wyer P, et al. Evidence-Based Medicine Teaching Tips Working Group: Tips for learners of evidence-based medicine: 4. Assessing heterogeneity of primary studies in systematic reviews and whether to combine their results. CMAJ, 2005, 172: 661-665. [Medline] [CrossRef]

22) DerSimonian R, Laird N: Meta-analysis in clinical trials. Control Clin Tri- als, 1986, 7: 177-188. [Medline] [CrossRef]

23) Egger M, Smith GD, Phillips AN: Meta-analysis: principles and procedures. BMJ, 1997, 315: 1533-1537. [Medline] [CrossRef]

24) Lance J: Spasticity: disordered motor control. In: Symposium synopsis. Miami: Year Book Medical Publishers, 1980, pp 485-494.

25) Berger W, Horstmann G, Dietz V: Tension development and muscle activation in the leg during gait in spastic hemiparesis: independence of muscle hypertonia and exaggerated stretch reflexes. J Neurol Neurosurg Psychiatry, 1984, 47: 1029-1033. [Medline] [CrossRef]

26) Thompson AJ, Jarrett L, Lockley L, et al.: Clinical management of spasticity. J Neurol Neurosurg Psychiatry, 2005, 76: 459-463. [Medline] [CrossRef]

27) Gonkova MI, Ilieva EM, Ferriero G, et al.: Effect of radial shock wave therapy on muscle spasticity in children with cerebral palsy. Int J Rehabil Res, 2013, 36: 284-290. [Medline] [CrossRef]

28) Amelio E, Manganotti P: Effect of shock wave stimulation on hypertonic plantar flexor muscles in patients with cerebral palsy: a placebo-controlled study. J Rehabil Med, 2010, 42: 339-343. [Medline] [CrossRef]

29) Moon SW, Kim JH, Jung MJ, et al.: The effect of extracorporeal shock wave therapy on lower limb spasticity in subacute stroke patients. Ann Rehabil Med, 2013, 37: 461-470. [Medline] [CrossRef]

30) Sohn MK, Cho KH, Kim YJ, et al.: Spasticity and electrophysiologic changes after extracorporeal shock wave therapy on gastrocnemius. Ann Rehabil Med, 2011, 35: 599-604. [Medline] [CrossRef]

31) Manganotti P, Amelio E: Long-term effect of shock wave therapy on upper limb hypertonia in patients affected by stroke. Stroke, 2005, 36: $1967-$ 1971. [Medline] [CrossRef]

32) Thibaut A, Chatelle C, Ziegler E, et al.: Spasticity after stroke: physiology, assessment and treatment. Brain Inj, 2013, 27: 1093-1105. [Medline] [CrossRef]

33) Spira R: Management of spasticity in cerebral palsied children by peripheral nerve block with phenol. Dev Med Child Neurol, 1971, 13: 164-173. [Medline] [CrossRef]

34) Yadav SL, Singh U, Dureja GP, et al.: Phenol block in the management of spastic cerebral palsy. Indian J Pediatr, 1994, 61: 249-255. [Medline] [CrossRef]

35) Tardieu G, Tardieu C, Hariga J, et al.: Treatment of spasticity in injection of dilute alcohol at the motor point or by epidural route. Clinical extension of an experiment on the decerebrate cat. Dev Med Child Neurol, 1968, 10: 555-568. [Medline] [CrossRef]

36) Burbaud P, Wiart L, Dubos JL, et al.: A randomised, double blind, placebo controlled trial of botulinum toxin in the treatment of spastic foot in hemiparetic patients. J Neurol Neurosurg Psychiatry, 1996, 61: 265-269. [Medline] [CrossRef]

37) Corry IS, Cosgrove AP, Walsh EG, et al.: Botulinum toxin A in the hemiplegic upper limb: a double-blind trial. Dev Med Child Neurol, 1997, 39: 185-193. [Medline] [CrossRef]

38) El O, Peker O, Kosay C, et al.: Botulinum toxin A injection for spasticity in diplegic-type cerebral palsy. J Child Neurol, 2006, 21: 1009-1012. [Medline] [CrossRef]

39) Fehlings D, Rang M, Glazier J, et al.: An evaluation of botulinum-A toxin injections to improve upper extremity function in children with hemiplegic cerebral palsy. J Pediatr, 2000, 137: 331-337. [Medline] [CrossRef]

40) Koman LA, Mooney JF 3rd, Smith BP, et al.: Management of spasticity in cerebral palsy with botulinum - A toxin: report of a preliminary, randomized, double-blind trial. J Pediatr Orthop, 1994, 14: 299-303. [Medline] [CrossRef]

41) Lagalla G, Danni M, Reiter F, et al.: Post-stroke spasticity management with repeated botulinum toxin injections in the upper limb. Am J Phys Med Rehabil, 2000, 79: 377-384, quiz 391-394. [Medline] [CrossRef]

42) Buckon CE, Thomas SS, Piatt JH Jr, et al.: Selective dorsal rhizotomy versus orthopedic surgery: a multidimensional assessment of outcome efficacy. Arch Phys Med Rehabil, 2004, 85: 457-465. [Medline] [CrossRef]

43) Wright FV, Sheil EM, Drake JM, et al.: Evaluation of selective dorsal rhizotomy for the reduction of spasticity in cerebral palsy: a randomized controlled trial. Dev Med Child Neurol, 1998, 40: 239-247. [Medline] [CrossRef]

44) McLaughlin JF, Bjornson KF, Astley SJ, et al: Selective dorsal rhizotomy: efficacy and safety in an investigator-masked randomized clinical trial. Dev Med Child Neurol, 1998, 40: 220-232. [Medline] [CrossRef]

45) Penn RD, Savoy SM, Corcos D, et al.: Intrathecal baclofen for severe spinal spasticity. N Engl J Med, 1989, 320: 1517-1521. [Medline] [CrossRef]

46) Albright AL, Cervi A, Singletary J: Intrathecal baclofen for spasticity in cerebral palsy. JAMA, 1991, 265: 1418-1422. [Medline] [CrossRef]

47) Gilmartin R, Bruce D, Storrs BB, et al.: Intrathecal baclofen for management of spastic cerebral palsy: multicenter trial. J Child Neurol, 2000, 15: 
71-77. [Medline] [CrossRef]

48) Van Schaeybroeck P, Nuttin B, Lagae L, et al.: Intrathecal baclofen for intractable cerebral spasticity: a prospective placebo-controlled, doubleblind study. Neurosurgery, 2000, 46: 603-609, discussion 609-612. [Medline] [CrossRef]

49) Jankovic J, Schwartz KS: Longitudinal experience with botulinum toxin injections for treatment of blepharospasm and cervical dystonia. Neurology, 1993, 43: 834-836. [Medline] [CrossRef]

50) Siatkowski RM, Tyutyunikov A, Biglan AW, et al.: Serum antibody production to botulinum A toxin. Ophthalmology, 1993, 100: 1861-1866. [Medline] [CrossRef]

51) Shrivastava SK, Kailash : Shock wave treatment in medicine. J Biosci, 2005, 30: 269-275. [Medline] [CrossRef]

52) Molina JA, Jiménez-Jiménez FJ, Ortí-Pareja M, et al.: The role of nitric oxide in neurodegeneration. Potential for pharmacological intervention. Drugs Aging, 1998, 12: 251-259. [Medline] [CrossRef]

53) Gotte G, Amelio E, Russo S, et al.: Short-time non-enzymatic nitric oxide synthesis from L-arginine and hydrogen peroxide induced by shock waves treatment. FEBS Lett, 2002, 520: 153-155. [Medline] [CrossRef]

54) Lieber RL, Steinman S, Barash IA, et al.: Structural and functional changes in spastic skeletal muscle. Muscle Nerve, 2004, 29: 615-627. [Medline] [CrossRef]

55) Chang KV, Chen SY, Chen WS, et al.: Comparative effectiveness of focused shock wave therapy of different intensity levels and radial shock wave therapy for treating plantar fasciitis: a systematic review and network meta-analysis. Arch Phys Med Rehabil, 2012, 93: 1259-1268. [Medline] [CrossRef]

56) Foldager CB, Kearney C, Spector M: Clinical application of extracorporeal shock wave therapy in orthopedics: focused versus unfocused shock waves. Ultrasound Med Biol, 2012, 38: 1673-1680. [Medline] [CrossRef]

57) Mittermayr R, Antonic V, Hartinger J, et al.: Extracorporeal shock wave therapy (ESWT) for wound healing: technology, mechanisms, and clinical efficacy. Wound Repair Regen, 2012, 20: 456-465. [Medline]

58) Ashworth B: Preliminary trial of carisoprodol in multiple sclerosis. Practitioner, 1964, 192: 540-542. [Medline]

59) Morris S: Ashworth and Tardieu Scales: their clinical relevance for measureing spasticity in adult and paediatric neurological populations. Phys Ther Rev, 2002, 7: 53-62. [CrossRef]

60) Pandyan AD, Johnson GR, Price CI, et al.: A review of the properties and limitations of the Ashworth and modified Ashworth Scales as measures of spasticity. Clin Rehabil, 1999, 13: 373-383. [Medline] [CrossRef]

61) Mehrholz J, Major Y, Meissner D, et al.: The influence of contractures and variation in measurement stretching velocity on the reliability of the Modified Ashworth Scale in patients with severe brain injury. Clin Rehabil, 2005, 19: 63-72. [Medline] [CrossRef]

62) Mehrholz J, Wagner K, Meissner D, et al.: Reliability of the Modified Tardieu Scale and the Modified Ashworth Scale in adult patients with severe brain injury: a comparison study. Clin Rehabil, 2005, 19: 751-759. [Medline] [CrossRef] 